\title{
Bridging the SME Financing Gap in Ghana: The Role of Microfinance Institutions
}

\author{
Isaac Quaye ${ }^{1}$, Eugene Abrokwah ${ }^{2}$, Alfred Sarbah ${ }^{*}$, Joseph Yaw Osei ${ }^{3}$ \\ ${ }^{1}$ School of Management \& Economics, University of Electronic Science \& Technology of China, Chengdu, China \\ ${ }^{2}$ School of Business, University of Shanghai for Science and Technology, Shanghai, China \\ ${ }^{3}$ School of Business, Kwame Nkrumah University of Science and Technology, Kumasi, Ghana \\ Email: *sarbah@yahoo.com
}

Received 24 August 2014; revised 25 September 2014; accepted 16 October 2014

Academic Editor: Grigorios L. Kyriakopoulos, National Technical University of Athens (NTUA), Greece

Copyright (C) 2014 by authors and Scientific Research Publishing Inc.

This work is licensed under the Creative Commons Attribution International License (CC BY).

http://creativecommons.org/licenses/by/4.0/

\section{(c) (i) Open Access}

\section{Abstract}

Financing Small and Medium-Scale Enterprises (SMEs) to achieve the desirable growth and expansion has been topical for governments, policymakers, non-governmental organizations (NGOs), financial and non-financial institutions. The recent upsurge in the interest of finding ways of bridging the financing gap faced by SMEs by these stakeholders have been necessitated by the enormous contributions of SMEs to the economic development and growth of countries in areas of job creation, GDP and entrepreneurial skill development. This research therefore sought to access the role of one of the stakeholders, microfinance institutions (MFIs) in helping to bridge the financing gap faced by SMEs in Ghana. The research established that there was indeed the existence of SME financing gap in the country as most of them were denied access to credit by commercial banks and other financial institutions. The research revealed that the operations of microfinance institutions (MFIs) are having positive impact on SMEs. The study also revealed some risk mitigation tools used by MFIs in granting loans to SMEs which included provision of collateral security in the form of land or any other valuable asset, business records, credit history among others. The research concluded with some recommendations on how the SME financing gap can further be bridged by MFIs and other stakeholders which included provision of support services to SMEs by MFIs such as training services in credit management as well as the need for MFIs to improve service delivery such as faster loan approval times.

\section{Keywords}

SMEs, Financing Gap, Microfinance Institutions, Ghana

\footnotetext{
${ }^{*}$ Corresponding author.
} 


\section{Introduction}

The growth of SMEs has been in the recent past a great concern to many governments, policy makers and researchers universally because of realization of their economic contribution to Gross Domestic Product (GDP) and economic growth. As such they are no longer viewed as "stepping stones" to real business but as a means of industrial and economic growth and as well as tools of poverty eradication [1]. The importance of SMEs in contributing to job creation and output growth is now widely accepted in both developed and developing countries [2]. The process of expansion of these enterprises from very small into medium size is of particular interest. Growth-oriented SMEs make their most tangible contribution to economic growth and job creation when they grow from very small into medium size enterprises. Dynamic medium-sized enterprises provide a competitive edge in two ways - as leading subcontractors and as venture firms in their own right. They also tend to survive longer than most SMEs and create jobs that yield higher returns, thus multiplying their impact on economic growth [3].

The development of SMEs is seen as accelerating the achievement of wider economic and socio-economic objectives, including poverty alleviation [4]. SMEs produce about 25\% of OECD exports and 35\% of Asia's exports [5]. SMEs represent over $90 \%$ of private business and contribute to more than $50 \%$ of employment and of GDP in most African countries [6]. Small enterprises in Ghana are said to be a characteristic feature of the production landscape and have been noted to provide about $85 \%$ of manufacturing employment of Ghana [7] [8]. SMEs are also believed to contribute about 70\% to Ghana's GDP and account for about $92 \%$ of businesses in Ghana [9]. SMEs therefore have a crucial role to play in stimulating growth, generating employment and contributing to poverty alleviation, given their economic weight in developing countries [10]. However, SMEs also face many challenges in their day-to-day operations and ability to grow.

Access to finance is often cited as one of the primary obstacles that affect SMEs disproportionately [11], and lack of data has made it very difficult to determine the exact size of the financing gap [12]. Over 98\% of SMEs have no access to formal financing [13]. This lack of access to credit from the traditional financial sector is alarming in a situation where the poor represent the largest share of the population in many African countries and that the informal sector represents an integral part of the economy in these countries. A large number and variety of microfinance institutions have been established in recent years in Africa to serve the unsatisfied demand for financial services-particularly in the informal sector. These institutions focus on providing services to individuals and small businesses in either one or the combination of credit provision and deposit collection [14].

Notwithstanding the perceived high risk and default rate of small businesses by the traditional financial institutions, the situation is different with the microfinance industry. SMEs and individuals repay loans with very low defaults with relatively high interest rates. The viable market for financial products among the vast low income earners considered as the unbanked populations of the world, has been realized by banks and entrepreneurs in developing countries [15]. Microfinance has been able to succeed in the provision of financial assistance and aiding them to gradually gain financial freedom. This has been made possible through its strong competency in the utilization of scarce resources to effectively and efficiently serve the informal sector [16]. Much as the microfinance players concede, the market is big enough to accommodate the traditional and universal banks. They are determined to control as much share of the market as they can before the anticipated big competition takes full effect [17].

\section{Research Objectives}

The objectives of this research which seek to assess the role of microfinance institutions in bridging the SME financing gap would be:

- To ascertain the financing gap with regards SMEs in Ghana.

- To find how micro finance institutions aid in bridging SMEs' financing gap.

- To identify risk-mitigation tools used by microfinance institutions (MFIs) in lending credit to SMEs.

\section{Literature Review}

\subsection{Definition of SMEs}

The term SME is widely used to describe small businesses in the private sector. There is no single definition of Small and Medium Enterprises mainly because of its diversity of businesses. Definitions are basically based on the number of employees to those based on business turnover and assets. What exactly an SME is depends on 
who is doing the definition. SME therefore can be seen as an independent business, managed by its owner or part-owners and having a small market share [18]. Small business is regarded as one whose scale of operations is less than the average for the industry [19].

The European Commission has defined SMEs as organizations employing fewer than 250 people [20]. Since 1976, the World Bank defines SMEs as firms with fixed assets (excluding land) less than US\$250,000 in value [21]. In Ghana, the widely used criterion in defining SMEs is the number of employees. However, there are always divergence views with regard to the maximum number of employees used by the various official institutions. The National Board for Small Scale Industries (NBSSI, 1990) defines a small-scale enterprise as a firm with not more than 9 workers, and has plant and machinery (excluding land, buildings and vehicles) not exceeding 10 million Ghanaian cedis and micro with employee less than five. The Ghana Enterprise Development Commission (GEDC), on the other hand, uses a 10 million Ghanaian cedis upper limit definition for plant and machinery [22]. A more recent definition is the one given by the Regional Project on Enterprise Development Ghana manufacturing survey paper which defines SMEs as businesses having lower than 100 workers [23]. SMEs are categorized into four; micro enterprises are those that less than 6 employees; very small enterprises constitute those employing 6 - 9 employees; small enterprises are businesses that employ between 10 and 29 workers while medium sized enterprises are those that employ between 29 to 50 employees [24]. The research adopts this definition as it paves way for more SMEs to be included in the research.

\subsection{SME Financing Gap}

The presence and nature of a "finance gap" for small firms has been debated for decades ever since the publishing of the Macmillan Report [25]. Small firms have been noted as being frequently under-capitalized. That is, the term structure of loans granted to SMEs does not suit their needs. In instances when SMEs are given credit, they are often granted short-term loans and therefore they have no option but to depend on short-term [26] and informal credits in financing their long-term needs such as acquiring new equipment [27]. There is some controversy as to whether it is meaningful to speak of a "financing gap" theoretically [28]. Clearly, there can be such a gap if the authorities intervene in the market and maintain interest rates below the equilibrium rate, which would inevitably lead to excess demand for loanable funds.

In the past, some analysts argued that it was not meaningful to speak of a funding gap unless the authorities actually kept interest rates below market clearing levels. It was held that as risks rise, providers of financial resources would sufficiently increase interest rates charged to all borrowers to bring the supply and demand for credit into balance. In modern financial systems surplus funds may pass from "savers" to borrowers through intermediated channels (e.g. banking, securitization) or may be allocated directly to borrowers [29]. At its core the process of financial intermediation is about processing information from one form to another. Thus, this process concedes that banks and other intermediaries could add value via diversification as it entails expanding the investment choices available to savers and the sources of credit for borrowers [30].

In examining the financial intermediation process, it is important to note that, because the supply of credit is inexhaustible, there will always be some borrowers whose demand for credit is not satisfied in full or terms they consider inappropriate [31]. In the competition for credit, borrowers whose credit risk is relatively easy to assess have the advantage while entities such as SMEs are more likely to have their requests denied [32]. In fact even in banking markets that are fully competitive and have no major structural distortions. SMEs may well be at a considerable disadvantage in obtaining finance compared with more established companies. Obviously the possibility that large number of small firms will be excluded from the credit market becomes even higher as market imperfections gain in significance. Argument to this effect are frequently made concerning SMEs, in particular, that there are systematic gaps in the debt market for SMEs [33]. Therefore, financing gap is a term that is typically meant to imply that a sizeable share of otherwise economically relevant SMEs that cannot obtain financing from banks, capital markets or otherwise suppliers of finance for their "viable projects" because the flow of credit would be affected by changes in either the demand or the supply of credit.

Thus in defining a financing gap it is necessary to distinguish between the two issues [34]. Countries with the private credit market, with moderate amount of financial assistance; have apparently succeeded in providing sufficient financial resources to SME sector broadly defined, such that no generalized financing gap can be identified. Competition has spurred financial institutions to devise innovative solutions, combined with a measured amount of public support have enabled the financial system to surmount the information and agency problems that characterize SME lending. This same positive assessment does not necessarily apply in the case of emerging economies and developing countries. In most countries the majority of SMEs appear to be facing a 
persistent challenge in obtaining credit. There are macro-economic policies that lead to excess for domestic savings, regulatory and structural policies that favor larger enterprises. These have got a tendency or provide incentive for SMEs to remain in the informal economy and patterns of ownership, governance and supervision that discourage banks from lending to SMEs are contributing factors [35]. If the business landscape can be visualized as a pyramid as depicted in Figure 1, financing gap is a problem particularly for SMEs unlike microenterprises and large firms [36].

\subsection{Causes of SME Financing Gap}

A major barrier to rapid development of the small and medium enterprises sector is a shortage of both debt and equity financing. Accessing finance has been identified as a key element for small and medium enterprises to succeed in their drive to build productive capacity, to compete, to create jobs and to contribute to poverty alleviation in developing countries. Without finance, small and medium enterprises cannot acquire or absorb new technologies nor can they expand to compete in global markets or even strike business linkages with larger firms [37]. Below are some of the causes of finance gap in SMEs:

\subsubsection{Perceived High Risks}

Commercial banks are usually wary of small businesses because of the perception that SMEs are high risk borrowers. This systematic bias against SMEs can be explained by Akelofs theory "market for lemons" [38] which is illustrated in Figure 2. Because small businesses are regarded as high risk, the level of risk associated with the riskiest small business tends to be applied to all businesses. Consequently bad business tend to drive good business out of financial markets as the latter have to raise equity or debt terms than to exaggerate their risk. The gap between true risk and the perceived risk can be termed as the lemon gap.

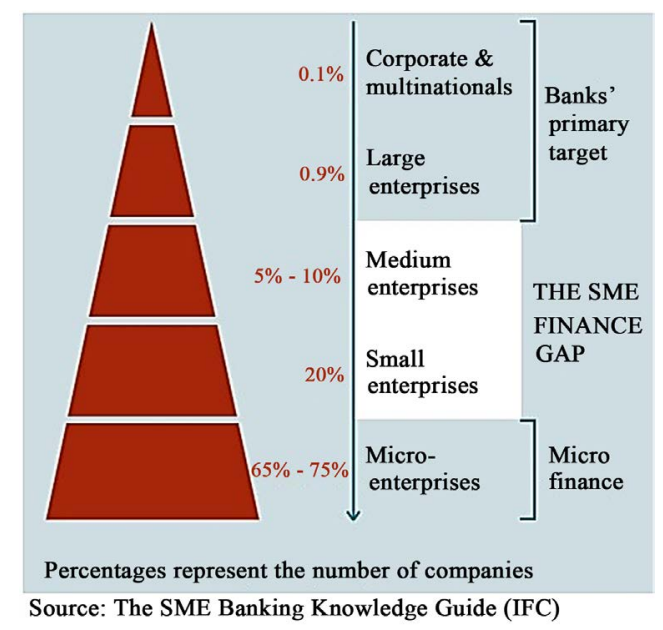

Figure 1. Composition of business structure in emerging economies.

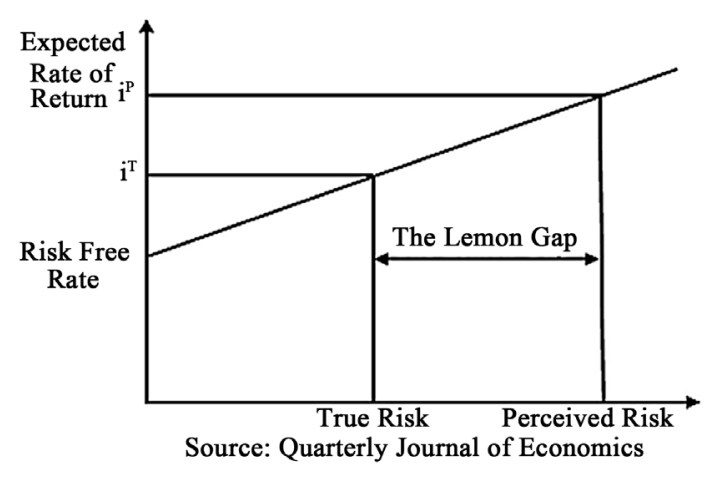

Figure 2. Risk and return faced by SMEs. 


\subsubsection{Lack of Collateral}

Lack of collateral hinders access to credit and is usually related to poorly defined property, land use rights, weak land and property markets [39]. Stringent collateral requirements of formal institutions often rule out a large segment of SMEs. Since there is considerable uncertainty surrounding the survival and growth of SMEs and their asset-backed collateral is usually valued at "carcass value" to ensure that the loan is realistically covered in case of default and immediate realization. Even when borrowers have assets that can be used as collateral, they are often not acceptable to banks because of high cost and long delays in using judicial enforcement mechanisms [40]. This implies that the already disadvantaged small firms may even need proportionately more collateral than do large firms.

\subsubsection{Reputational Effects}

They apply theoretically where SME owners are prevented by their own or other experiences from applying for debt finance. This provides a discouraged borrower effect [41] [42]. That is, some small business owners may not access finance because at some stage they are discouraged from applying. For instance, business owners, who are discouraged by perceived bureaucracy or financial requirements and are discouraged by a first refusal. Entrepreneurs may not seek finance if there are perceived issues. This could be either that they think they will be unsuccessful so there is little point in applying or a perception that they will not have the information and good credit history that it is perceived that banks require. It may occur where entrepreneurs from certain groups distrust bankers, as for example can occur with ethnic minority entrepreneurs since they may perceive institutional bias in banking institutions [43]. The extent of any discouraged borrower effect is unknown. It has been suggested that banks with extensive and close relationships with some small firm communities may be able to overcome these adverse effects.

\subsubsection{Existence of Information Asymmetries between Finance Providers and Borrowers}

Information asymmetries refer to disparities between information available to businesses seeking capital and suppliers of capital who are typically assumed to be at an informational disadvantage with respect to insiders of the business [44] [45]. SMEs do not publish the same quantity or quality of financial information than publicly held firms. As a result, information on their financial condition, earnings and earnings prospects may be incomplete or inaccurate. Faced with this type of uncertainty, a lender may deny credit, sometimes to firms that are credit worthy but unable to document it [46].

These, for example, include new and technology-based propositions for which market intelligence will be limited and asymmetric information is more acute. At an early stage, information is limited and not always transparent [47] [48] and assets are often knowledge based exclusively associated with the founding entrepreneur [49]. Especially with manufacturing or technology based firms, entrepreneurs may be reluctant to provide full information about the opportunity because of concerns that disclosure may make it easier for others to exploit [50]. In addition, there may be asymmetries arising from location as well as sector. For example, owners of SMEs in rural environments may face difficulties with access to bank finance [51]. However, many non-financial constraints inhibit the success of such enterprises. SME owners are reluctant to be transparent or open up their businesses to outsiders. They seem to be unaware of their obligations and responsibilities they have toward capital providers, and the need to acquire or seek support for technical services like accounting, management, marketing, strategy development and establishment of business linkages [52].

\subsection{Bridging the Financing Gap in SMEs in Developing Countries}

Supply and access to capital are critical to stimulating entrepreneurship, family businesses and economic growth. The International Finance Corporation (IFC) estimates that up to $84 \%$ of small and medium-sized enterprises (SME's) in Africa are either un-served or underserved, representing a value gap in credit financing of USD 140 170 billion [53]. Four pronged approaches to bridging the finance gap in developing countries are as discussed below [54].

\subsubsection{Making the Financial System More Accessible}

Most African financial systems are fragmented. The "missing middle" in the pattern of size of firm is matched by one in the range of financing available. Lack of funding for SMEs has partly been made up for by micro-credit 
institutions, whose growth is due to the flexible loans they offer small businesses. In Angola, Novobanco provides loans free of bank charges, without a minimum deposit and with informal guarantees (property assets and a guarantor), as well as permanent contact with loan managers. Though adapted to local needs, however, micro-credit institutions remain fragile and modest-sized. As well as lacking trained staff, micro-credit institutions face limited expansion because of their limited funds. Their mainly short-term finance means they cannot easily turn the savings they collect into medium or long-term loans. They are also up against the cost of refinancing through the formal banking sector and have no access to refinancing either by the central bank or by venture capital.

Microcredit institutions could be put on a firmer financial footing by developing and adapting long-term savings products that exist elsewhere, such as life insurance and home-saving plans, and encouraging the setting up of specialized refinance banks such as Mali’s "solidarity bank" (Banque malienne de solidarité), or working more closely with the formal banking sector (Benin's SME support organization PAPME and the local Bank of Africa). Some countries (such as Kenya) have dealt with the lack of funding by supporting growth of smaller commercial banks or (in Ghana) of rural banks, so as to bring traditional banks and SMEs closer geographically and business-wise.

South Africa passed two laws in early 2005 to expand the banking system to include savings and loan institutions (second-tier banks) and co-operative banks (third-tier banks) while easing banking regulations so the newcomers could still be flexible in providing loans. In many countries, commercial banks are also setting up their own micro-credit services. Removing the obstacles to access for SMEs' to finance requires that commercial banks, micro-credit institutions, community groups and business development services (BDS) work closely together. Pushing for agreements between financial bodies and BDS suppliers will help make up for lack of capacity and reduce costs by more efficient division of labor. The BDS supplier makes the initial choice of projects on a purely technical basis and the credit institution looks at financial viability. Making loans to intermediaries (NGOs and federations of SMEs) with the job of allotting funds to members can also help cut administration costs. Solidarity between banks, especially setting up inter-bank financing to (as in Nigeria) pool money to be invested in SMEs, reduces the extra risk of lending to SMEs, as well. Working with banks boosts the financial viability of micro-credit institutions and can also help informal financial bodies to move towards the formal sector.

\subsubsection{Improving Business Conditions}

Proper information, a key to deciding whether to make a loan, would be helped by adopting clear accounting standards, setting up independent, competent and reputable accounting firms and creating more credit bureau supplying data on the solvency of firms. An impartial legal system that can help settle contract disputes, commercial law reform and drafting and clarifying land titles, as well as effective bankruptcy procedures, are vital for growth of the business sector. A country's tax laws can either coax small businesses into the formal sector of the economy or keep them out of it. Governments should also make sure that they pay SMEs promptly, since public contracts are vital to the financial security of these firms.

\subsubsection{Expanding the Supply of Finance through the Non-Financial Private Sector}

Financial institutions are not the only source of money for SMEs. Apart from remittances by nationals working abroad, which are a key boost to private-sector growth, the interdependence between SMEs, large firms and sectoral "clusters" is a major potential source of finance. Big firms can do a lot to help SMEs get finance more easily by transferring resources (money and factors of production) and guaranteeing SME solvency with financial institutions. Links with major companies can also help SMEs get export credits, which are especially important in countries with weak institutions, since commercial partners are better informed than other creditors (especially financial institutions) about the ability of their customers to repay debts.

Export credits have been proved useful in Zambia's agro-food industry. Subcontracting is still uncommon in Africa, but has grown rapidly in South Africa since 1998, though there is increasing skepticism about it because it may confine SMEs to low-skill informal activities. Clusters of SMEs, which are very active in Asia, enable member firms to seek finance together, provide collective guarantees or even set up their own financial body. The threat of expulsion from the cluster ensures that promises are kept, which allows the network to overcome shortcomings in the legal system. Frequent interaction with financial authorities, as well as the role that reputation plays in the cluster, can greatly increase confidence between firms and financial institutions and thus make it easier to get loans and lower rates of interest. Working together also means firms can get supplier credits and can 
borrow from each other when necessary, which reduces general costs. Such clusters, however, are very little developed in Africa and are concentrated in South Africa, Kenya, Nigeria, Tanzania and Zimbabwe.

\subsubsection{Helping SMEs Meet the Requirements of Formal Financing}

Apart from the need to boost SME capacities, some financial instruments can help provide missing information or reduce the risk stemming from some SMEs' lack of transparency. Franchising, which is very popular in Southern and East Africa with the encouragement of South Africa, allows use of a brand name or know-how that reduces the risk of failure. Warehouse-receipt financing (in South Africa, Kenya and Zambia) guarantees loans with agricultural stocks. Other financial instruments, such as leasing and factoring, can reduce risk effectively for credit institutions but are still little used in Africa. Credit associations that reduce risk by sharing it are more common. They help financial institutions choose to whom to lend, by guaranteeing the technical viability of projects, and sometimes providing guarantees. But growth of these bodies is limited by the lack of organization among SMEs in Africa and by their focus on certain sectors and geographical areas. Governments and donor sources have thus preferred creation of guarantee funds to ensure repayment in case of default. In several countries, especially in Central Africa, this has not worked since provision of a guarantee has meant less rigorous choice of investment projects and a lower rate of debt recovery. Elsewhere, notably in Mozambique, borrowers and financial institutions have worked together to maintain a good rate of recovery and to reduce interest rates.

\subsection{Over View of Microfinance in Ghana}

The term microfinance refers to a development tool that grants or provides financial services and products such as very small loans, savings, micro-leasing, micro-insurance and money transfer to assist the very or extremely poor in growing or establishing their businesses. It is mostly used in developing economies where SMEs do not have access to other sources of financial assistance [55]. Microfinance encompasses the provision of financial services and the management of small amounts of money through a range of products and a system of intermediary functions that are targeted at low income clients. Microfinance may also refer to provision of small loans and other facilities like savings, insurance, transfer services to poor low-income household and microenterprises. Microcredit also refers to a small loan to a client made by a bank or other institutions [56].

The concept of microfinance is not new in Ghana. Traditionally, people have saved with and taken small loans from individuals and groups within the context of self-help to start businesses or farming ventures. Available evidence also suggests that the first Credit Union in Africa was established in Northern Ghana in 1955 by Canadian Catholic Missionaries. "Susu", which is one of the current microfinance methodologies, is thought to have originated in Nigeria and spread to Ghana in the early twentieth century [57]. Microfinance has gone through four (4) distinct phases worldwide of which Ghana is no exception. These stages are described below:

Phase One: The provision of subsidized credit by Governments starting in the 1950's when it was assumed that the lack of money was the ultimate hindrance to the elimination of poverty.

Phase Two: Involved the provision of micro credit mainly through NGOs to the poor in the 1960's and 1970's. During this period sustainability and financial self-sufficiency were still not considered important.

Phase Three: In the 1990's the formalization of Microfinance Institutions (MFIs) began.

Phase Four: Since the mid 1990's the commercialization of MFIs has gained importance with the mainstreaming of microfinance and its institutions into the financial sector.

In Ghana, the term microfinance is understood as a sub-sector of the financial sector, comprising mostly of different financial institutions who use a particular financial method to reach out to the poor and small businesses. Microfinance sector in Ghana comprises various types of institutions and these have been grouped into four (4) categories. These are:

- Formal suppliers such as savings and loans companies, rural and community banks, as well as some development and commercial banks;

- Semi-formal suppliers such as credit unions, financial non-governmental organizations (FNGOs), and cooperatives;

- Informal suppliers such as susu collectors and clubs, rotating and accumulating savings and credit associations (ROSCAs and ASCAs), traders, moneylenders and other individuals.

- Public sector programmes that have developed financial and nonfinancial services for their clients. 


\subsection{Profile of the Case Study Adopted (Kumasi Metropolis)}

The Kumasi metropolis is the most populous district in the Ashanti Region. During the 2000 Population Census it recorded a figure of 1,170,270 [58]. However, Kumasi metropolis recorded population figure of 2,035,064 [59] during the 2010 Population and Housing Census. According to the 2010 Population and Housing Census, Kumasi is the most populous city in Ghana. Kumasi has attracted such a large population partly because it is the regional capital, and also the most commercialized center in the region. Other reasons include the centrality of Kumasi as a nodal city with major arterial routes linking it to other parts of the country and also the fact that it is an educational center with two State Universities, Private Universities, a Polytechnic, two Teacher Training Colleges, Secondary Schools and a host of Basic Schools.

Ashanti Region is currently the most urbanized in the country. The large urban population in the region is mainly due to the fact that the Kumasi metropolis is not only entirely urban but accounts for a third of the region's population. The growth of industries and the large volume of commercial activity in and around Kumasi as well as the high migrant number may account partly for the relatively high urban population. The high population growth rate as well as rigorous commercial activities in the city has resulted in the establishment of many financial institutions including several microfinance institutions (MFIs). It has been estimated to have a daytime population of about 2 million. The population has grown rapidly over the intercensal periods from 346,336 in 1970 ; 487,504 in 1984; 1,170,270 in 2000; and 2,035,064 in 2010.

\section{Methodology}

The issues concerning assessing the roles of microfinance institutions in bridging the financing gap for SMEs are so diverse that a study would require in-depth analysis which calls for the need for case study. Case study is a form of research approach which allows detailed investigations of individuals, groups, institutions or other social units [60]. It is a strategy for doing research which involves an empirical investigation of a contemporary phenomenon in its real life context using multiple sources of evidence [61]. The rationale behind the use of case study method as to know, understand and be conversant with the circumstances in order to explain, advice, decide on, defend or reject a given situation, condition and argument among others [60]. Therefore, a case study focuses on understanding a particular case in its complexity. The research is descriptive in nature and employs case study method in assessing the role of microfinance institutions in bridging the financing gap for SMEs in Ghana.

In doing this one region, among the ten regions in Ghana, that is Ashanti region, was selected as a case study and Kumasi which is the capital city of Ashanti Region of Ghana was chosen for the purposes of data collection and undergoing the study herein. Descriptive statistics such as tables, frequency, percentages and charts were used by the researchers to illustrate data necessary for the presentation and analysis of the data obtained the field. The field survey produced data from both Microfinance Institutions (MFIs) and their SMEs clients who make up the population of the study by administering structured questionnaires. The questionnaires produced data amongst others the general perception of owners of SMEs on the operations of MFIs in helping to close the SME financing gap.

Purposive simple method was used in attaining the sample size, by basically concentrating on selected MFIs and their SME clients within the Kumasi metropolis, the capital of Ashanti Region and its environs for the study. Purposive sampling enables the researcher to use his or her judgment to select cases that will best answer his or her research question(s) and to achieve his or her objective [62]. Therefore, a total of 260 sets of questionnaires were distributed which constituted 225questionnaires for SMEs and 35 questionnaires managers of MFIs. 226 out of the 260 questionnaires were received back which were made up of 26 sets by MFIs and 200 sets by their SME clients. This represented response rate of $86.92 \%$. Statistical Package for Science Solutions (SPSS) was used to code the field data obtained in order to facilitate data entering and a comprehensive analysis and interpretation through the use of quantitative analysis techniques.

\section{Data Analysis/Findings}

The actual findings and analysis of data obtained from field survey are presented below:

\subsection{Finance Gap Faced by SMEs in Ashanti Region of Ghana}

One of the objectives of this study is to assess the finance gap faced by SMEs in Ghana using the city of Kumasi 
and its environs in Ashanti Region of Ghana as a case study. Traditional financial institutions have considered SME sector to be unattractive and un-bankable due to their perceived high risk and default rate and therefore SMEs are often denied access to credit. As a result, SMEs encounter finance gap in their attempt to seek for credit from banks.

Among the total 200 SMEs who took part in the research, 81\% of them said they have applied for loans from commercial banks of which only $16 \%$ were granted loans; leaving $65 \%$ being denied access to credit. Findings from the research also indicated that $19 \%$ of the respondents have never applied for loan from any commercial bank. These are shown in Figure 3 and Figure 4. The researcher therefore conducted interview to ascertain why majority of SMEs were denied access to credit. Some of the reasons given were poor management structure and low turnover. Additionally, their inability to provide business registration documents, landed and other forms of collateral security, proper financial statements or records, and business records account for this. It can be said from the above discussion that there is a gap between SMEs financing needs and the need to satisfy them from traditional financial institutions.

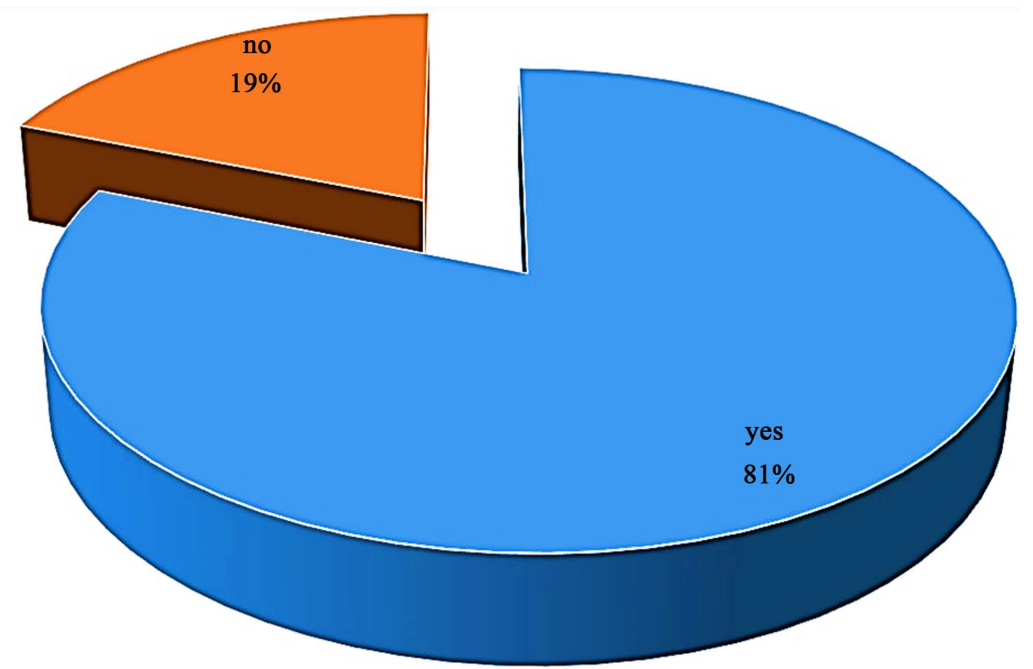

Source: Fieldwork (February, 2014)

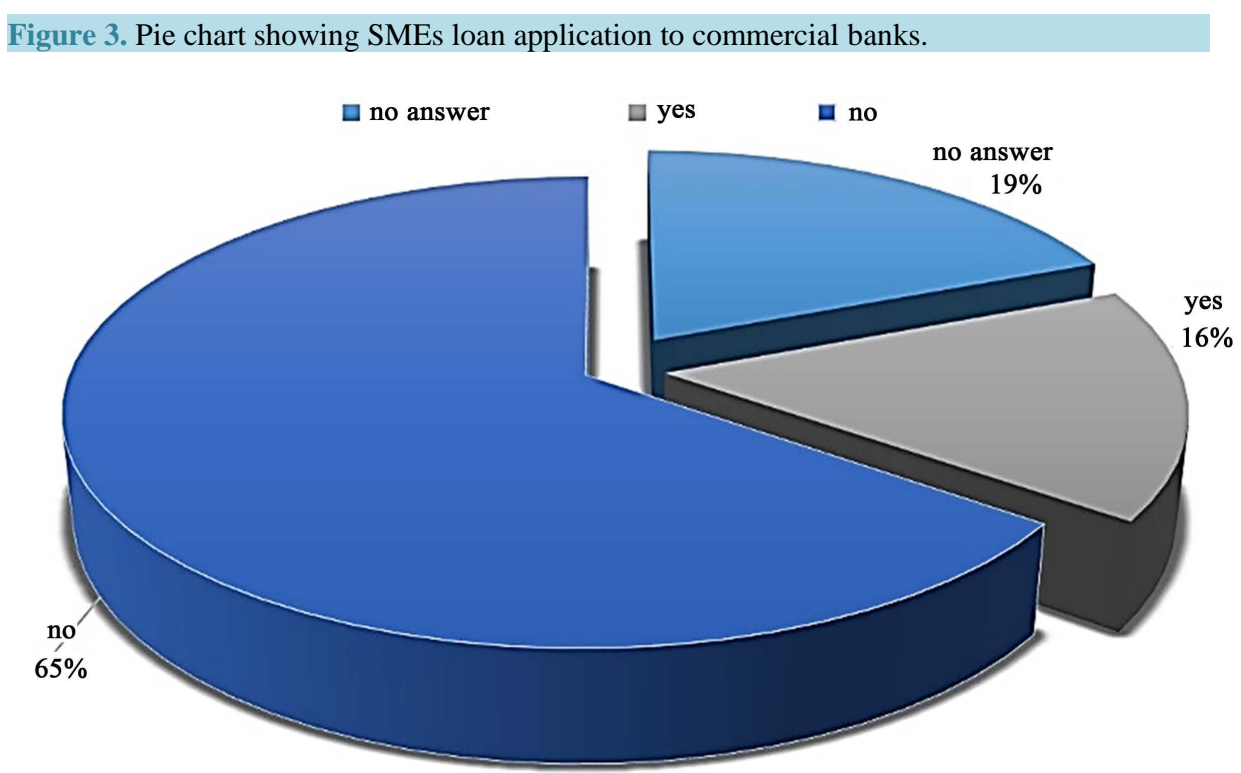

Source: Fieldwork (February, 2014)

Figure 4. Pie chart showing loan approval to SMEs by commercial banks. 


\subsection{Bridging the SMEs' Financing Gap by MFIs}

The development of SMEs can partly be attributed to the existence of MFIs. SMEs were asked through the questionnaires to state whether the operations of MFIs have positive or significant impact on their activities or otherwise. Among the 200 respondents for SMEs, 106\% or 53\% strongly agree that the operations of MFIs have positive impact on them. This is followed by 41 SMEs representing $21.5 \%$ chose the "agree" label while 23 SMEs or $11.5 \%$ opted for the "strongly disagree" label. This is followed by 17 SMEs or $8.5 \%$ and 13 SMEs or 6.5\% who chose the "disagree" and "no opinion" labels respectively. As shown in Figure 5, 53\% and 21.5\% of SMEs "strongly agree" and "agree" respectively that the operations of MFIs positively affects them. It can therefore be concluded that MFIs have helped and continually helping to bridge the SME financing gap. This is evidential in the research as $76.5 \%$ of SMEs are affected positively by the operations of MFIs. This is because MFIs that are financially sustainable with high outreach have a greater livelihood and also have a positive impact on SME development because they guarantee sustainable access to credit by the poor [63].

\subsection{Risk Mitigation Tools Used by MFIs}

SMEs applying for loans are supposed to fulfill certain requirements before these loans are granted or otherwise. These requirements are used to mitigate the risk that may arise due to the perception of high risk and default rate among SMEs.

11 out of the 26 respondents representing $42.3 \%$ said landed collateral is a requirement for SMEs whiles 15 respondents or $57.7 \%$ do not demand it from SME loan applicants as depicted in Table 1. 42.3\% of MFIs used for this research revealed that they require SMEs to provide landed collateral security before consideration of loans extension to them is made. Further one-on-one interview with the managers of these MFIs clarified that landed collateral security is greatly emphasized in a situation where the loan amount sought by an SME is very huge. Lack of proper housing and street naming system in Kumasi and Ghana in general coupled with perceived high risk and default rate among SMEs were some of the reasons given for such requirement. This is because it is extremely difficult to trace a defaulter who may relocate to another part of Ghana. The rest of the MFIs (15\% or $57.7 \%$ ) do not demand landed collateral from their SME clients. However, it became known through an interview with the managers of these MFIs that, they demand other forms of collateral security like motor vehicles, a house or any valuable property of the loan applicant when the loan amount is very huge. Generally, it can be said that all MFIs require one form of collateral security or the other.

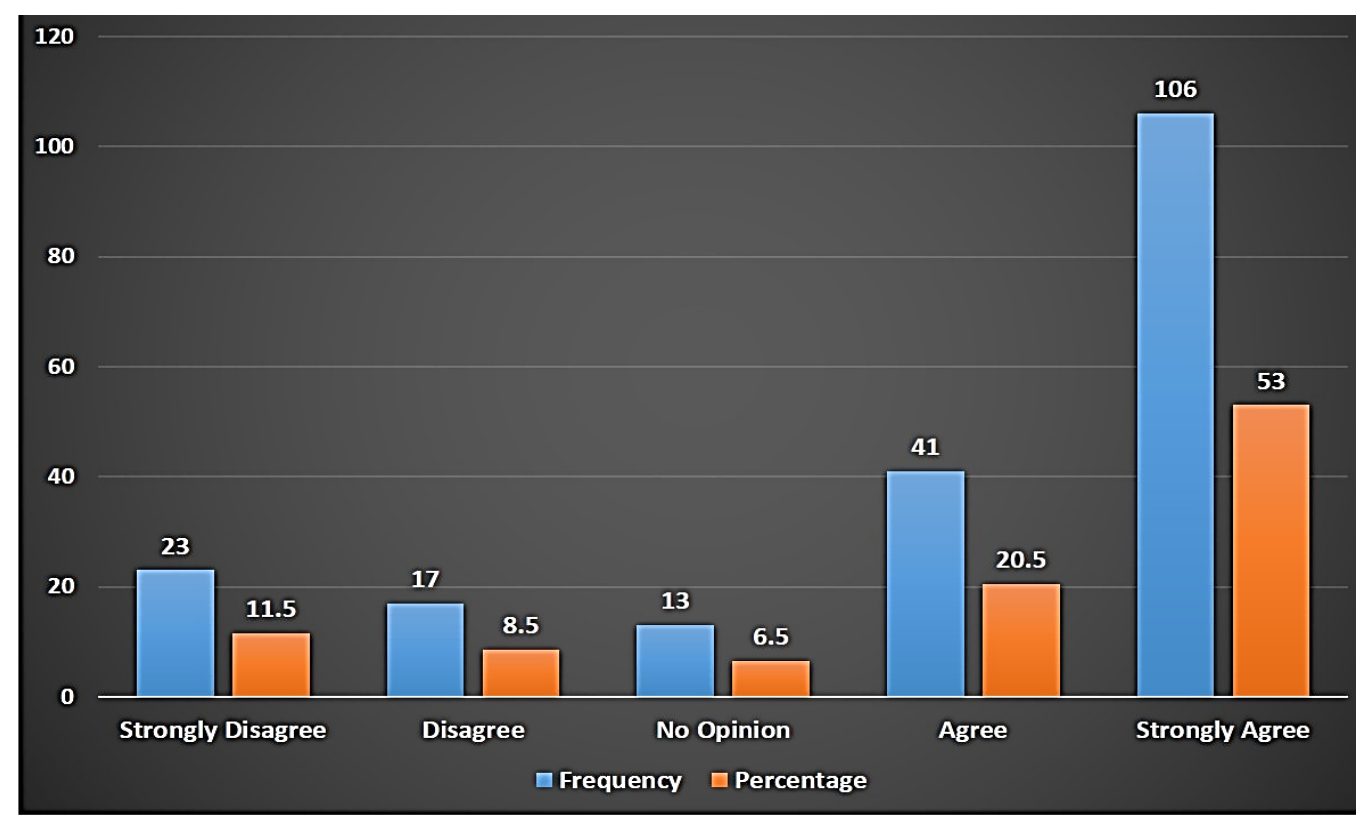

Source: Fieldwork, (February 2014)

Figure 5. Does MFIs' operations have positive impact on your business (SME)? 
On the questions as to whether business plan is a requirement, it has 0 respondents representing $76.9 \%$ as not a requirement for SMEs while 6 respondents or 23.1\% opted for "yes" label on the questionnaire indicating business plan is a risk mitigation tool used by the 6MFIsas illustrated in Table 2. Most SMEs lack formal managerial skills and financial ability to prepare proper business plan because of the low level of literacy among most SME operators. Consequently, business plan is not a major requirement for most MFIs (76.9\%). On the whole, it can be concluded that business plan is not a major requirement for SMEs seeking for credit from MFIs. The aforementioned reasons also account for why $16 \%$ or $61.5 \%$ of MFIs do not use asset turnover as a requirement for SMEs in their loan applications as depicted in Table 3.

Business records have 16 respondents or $61.5 \%$ of MFIs choosing the "yes" label whiles 10 respondents representing 38.5\% opted for the "no" label. As shown in Table 4, 61.5\% of the MFIs said that they demand some level of business records and information from their SME clients in approving loans. Since most SMEs could not provide audited financial statements, the MFIs require the business records and information to assist them assess the SME applicants' loan repayment capacity. The records may include receipts, invoices, sales records, location of business, years of operations, VAT payments and so on.

18 respondents representing 69.2\% are concerned with the credit history or records but 8 respondents or $30.8 \%$ indicated that they are less concerned about this requirement. This is illustrated in Table 5. Credit worthiness of loan applicants is very paramount to most MFIs in approving loans. MFIs will have high confidence level of no default in loan applicants with high credit worthiness. Thus, majority (69.2\%) of MFIs used in this study prefer SME loan applicants to furnish them with their credit history in order to ascertain their ability to default or otherwise.

Majority of the respondents made of $16 \%$ or $61.5 \%$ do not require SMEs to present guarantor in their loan application processes; however, $38.5 \%$ corresponding to 10 respondents for guarantor have set it as a requirement for loans advancement to SMEs as shown in Table 6. In recent years, the reliance on guarantors, particular individual ones by financial institutions in advancing loans is gradually becoming extinct. This action has been precipitated by unpleasant actions of some of the guarantors who vanish into thin air when the borrowers or debtors they guaranteed for default. Consequently, provision of guarantor(s) is/are not requirement for a large number (16\% or $61.5 \%)$ of MFIs but will prefer to demand for other requirements.

Table 1. Does your company use landed collateral security as risk mitigation tool in lending to SMEs?

\begin{tabular}{cccc}
\hline & Frequency & Percent & Cumulative Percent \\
\hline Yes & 11 & 42.3 & 42.3 \\
No & 15 & 57.7 & 100.0 \\
Total & 26 & 100.0 & \\
\hline
\end{tabular}

Source: Fieldwork (February, 2014).

Table 2. Does your company use business plan as risk mitigation tool in lending to SMEs?

\begin{tabular}{cccc}
\hline & Frequency & Percent & Cumulative Percent \\
\hline Yes & 6 & 23.1 & 23.1 \\
No & 20 & 76.9 & 100.0 \\
Total & 26 & 100.0 & \\
\hline
\end{tabular}

Source: Fieldwork (February, 2014).

Table 3. Does your company use asset turnover as risk mitigation tool in lending to SMEs?

\begin{tabular}{cccc}
\hline & Frequency & Percent & Cumulative Percent \\
\hline Yes & 10 & 38.5 & 38.5 \\
No & 16 & 61.5 & 100.0 \\
Total & 26 & 100.0 & \\
\hline
\end{tabular}

Source: Fieldwork (February, 2014). 
Table 4. Does your company use business records as risk mitigation tool in lending to SMEs?

\begin{tabular}{cccc}
\hline & Frequency & Percent & Cumulative Percent \\
\hline Yes & 16 & 61.5 & 61.5 \\
No & 10 & 38.5 & 100.0 \\
Total & 26 & 100.0 & \\
\hline
\end{tabular}

Source: Fieldwork (February, 2014).

Table 5. Does your company use credit history as risk mitigation tool in lending to SMEs?

\begin{tabular}{cccc}
\hline & Frequency & Percent & Cumulative Percent \\
\hline Yes & 18 & 69.2 & 69.2 \\
No & 8 & 30.8 & 100.0 \\
Total & 26 & 100.0 & \\
\hline
\end{tabular}

Source: Fieldwork (February, 2014).

Table 6. Does your company use guarantor as risk mitigation tool in lending to SMEs?

\begin{tabular}{cccc}
\hline & Frequency & Percent & Cumulative Percent \\
\hline Yes & 10 & 38.5 & 38.5 \\
No & 16 & 61.5 & 100.0 \\
Total & 26 & 100.0 & \\
\hline
\end{tabular}

Source: Fieldwork (February, 2014).

\section{Conclusions}

SMEs play a significant role in the economic development of Ghana and the general wellbeing of the citizenry. The growth of SMEs is usually hampered by limited access to credit especially by banks despite their significant contributions to economic development. MFIs have recognized and taken advantage of the gap created by banks in serving the financial needs of SMEs. Thus, the research indicated that the operations of MFIs have had positive impact on SMEs in the area of mobilization of savings, since MFIs have saving schemes which are less costly, easily accessible and take care of small amounts savers. The savings practice helps SMEs to increase their capital base since the owners of the SMEs plough back these savings into their businesses. In addition to the savings mobilization by MFIs, they also grant credit to SMEs which have helped bridged the SME financing gap to an extent. However, the risk mitigation tools and requirements instituted by MFIs serve as an impediment for some SMEs to access credit. It is therefore imperative for MFIs to close the SME financing gap further through the following recommendations made by the researchers.

MFIs are established for poverty alleviation and women empowerment. It is recommended that MFIs should come out with innovative and attractive products and services in order to accomplish the purposes for which they were established. These should be achieved through reduction of requirement for collateral, reduction in interest rates, flexible mode of payments and also sought for other relaxing risk mitigation tools. This will enable the SMEs access credit from them to run and expand their businesses.

The study recommends MFIs should support their SME clients by building long term and sustainable business relations, offer training services in credit management and improve service delivery such as faster loan approval times. In the long run, MFIs should embark on branch expansion drive to establish their presence in areas where their presence is yet to be established. Expanding their operations to other areas would enhance their contribution to savings mobilization and credit availability in the economy as a whole. This will help close SME financing gap further.

The closing of the financing gap faced by SMEs doesn't rest on the shoulders of only MFIs but other stakeholders including the SMEs themselves. Since it has been established by available literature and various re- 
searchers, banks and other financial institutions are unwilling to provide credit to SMEs. SMEs themselves can pool their resources together. The researcher recommends the establishment of a fund by SMEs situated in a particular locality where periodic contributions are made by all members into the pool. Member of SMEs in financial difficulty will be assisted at an interest lower than that offered by MFIs and other financial institutions.

Governments' role in supporting the SMEs sector must be deepened, especially where the financial system and the economic conditions in Ghana prevent SMEs from sourcing adequate financial assistance from MFIs and the financial sector in general on favorable terms. The efforts and measures of government in boosting the SME sector must be geared towards provision of incentives for the sector to inculcate into their operations an active SME finance policy.

The banking sector must be reformed in line with market-based principles, where the need arises. Government should act to enhance entrepreneurial awareness about the range of financing options at their disposal through MMDAs, MDAs, private investors and the banks. The government should create the enabling economic and business-friendly environment to attract many pro-SME private financial institutions and lenders. This can be achieved when the government adopts and implements policy and programmes aimed at producing favorable economic indicators such as inflation rate, exchange rate and interest rate. Consequently, MFIs will be able to meet the expectations of SMEs through dispensing loans to them at lower interest rate.

The researcher recommends the establishment of SME bank by the government. The purpose of this special bank is to solely deal with the needs of SMEs. The establishment of this bank will enable entrepreneurs to access credit facilities for expansion of their businesses without having to meet stringent requirements by MFIs and other financial institutions. The SME bank when established will appreciate and understand issues and challenges confronting SMEs and tailor innovative products and services to meet their needs. Moreover, unlike other financial institutions which have concentrated on dealing mostly with salary workers recently, the operations of SME bank will largely focus on SMEs. The SME bank will go a long way to further bridge the SME financing gap.

\section{References}

[1] ILO (1986) The Promotion of Small and Medium Sized Enterprises. International Labour Conference, 72nd Session, 1986. ILO Publications, Geneva.

[2] Mbuta and Nkandela (1998) The Impact of SMES on Economic Development.

[3] UNCTAD (2001) Growing Micro and Small Enterprises in LDCs. The "Missing Middle" in LDCs: Why Micro and Small Enterprises Are Not Growing”, UNCTAD/ITE/TEB/5.

[4] Cook, P. and Nixson, F. (2000) Finance and Small and Medium-Sized Enterprise Development. Finance and Development Research Programme Working Paper Series, 14, Institute for Development Policy and Management, University of Manchester.

[5] OECD (1997) Globalization and Small and Medium Enterprises, Synthesis Report, Organization for Economic Cooperation and Development.

[6] UNIDO (1999) SMEs in Africa Survive against All Odds. http://www.unido.org/doc/view?document_id=3927\&language_code=en

[7] Steel, W.F. and Webster, L.M. (1991) Small Enterprises in Ghana: Responses to Adjustment Industry. Series Paper, No. 33. The World Bank Industry and Energy Department, Washington DC.

[8] Aryeetey, E. (2001) Priority Research Issues Relating to Regulation and Competition in Ghana. Centre on Regulation and Competition Working Paper Series, University of Manchester, Manchester.

[9] Villars, J. (2004) Speech Delivered at a Workshop of the Ghana Investment Advisory Council. Akosombo, 5 June, 2004.

[10] Cofie, A.A. (2012) The Challenges of Financing Small and Medium Scale Enterprises (SMEs) in the Ashanti Region, A Case Study of Stanbic Bank (GH) Ltd. http://dspace.knust.edu.gh/bitstream/123456789/4292/1/Cofie\%20Alfred\%20Addotei.pdf

[11] Ayyagari, M., Demirgüç-Kunt, A. and Maksimovic, V. (2012) Financing of Firms in Developing Countries: Lessons from Research. Policy Research Working Paper 6036, World Bank, Washington DC.

[12] Peer, S., Oya, P.A. and Martin, H. (2013) Closing the Credit Gap for Formal and Informal Micro, Small, and Medium Enterprises. International Finance Corporation, World Bank Group, Washington DC.

[13] Lin, Y.F. (2007) Developing Small and Medium Bank to Improve Financial Structure. Working Paper, China Center 
for Economic Research, Peking University, Beijing.

[14] Basu, A., Blavy, R. and Yulek, M. (2004) Microfinance in Africa: Experience and Lessons from Selected African Countries. IMF Working Paper WP/04/174, World Bank, Washington DC.

[15] Firpo, J. (2005) Banking the Unbanked: Technology’s Role, Micro Capital.

[16] Appiah, M. (2008) Microfinance Development in Ghana: Achievements, Challenges and Issues for the Way forward. The Microfinance News.

[17] Boabeng, K.Y. (2009) The Informal Sector and the Microfinance Industry. 2nd Edition, Macmillan, New York.

[18] Bolton, J.E. (1971) Report of the Committee of Inquiry on Small Firms. HMSO, London.

[19] Oshagbemi, T.A. (1983) Small Business Management in Nigeria. Longman Nig. Ltd., Lagos.

[20] Burns, P. (2001) Entrepreneurship and Small Business. Great Britain.

[21] Katto, J. (2008) Financial Regulation of SMEs. IFAC Small and Medium Practices (SMP) Forum.

[22] Kayanula, D. and Quartey, P. (200) The Policy Environment for Promoting Small and Medium-Sized Enterprises in Ghana and Malawi. Finance and Development Research Programme Working Paper Series, 15. IDPM, University of Manchester, Manchester.

[23] Teal, F. (2002) Background Information on Use of Dataset: Regional Project on Enterprise Development (RPED), Ghana Manufacturing Sector Survey Waves I-V (1992-98). Centre for the Study of African Economies, Institute of Economics and Statistics, University of Oxford, Oxford.

[24] Osei, B., Baah-Nuakoh, A., Tutu, K. and Sowa, N. (1993) Impact of Structural Adjustment on Small-Scale Enterprises in Ghana. In: Helmsing, A. and Kolstee, T., Eds., Small Enterprise and Changing Policies: Structural Adjustment, Financial Policy and Assistance Programmes in Africa, IT Publications, London, 53-70. http://dx.doi.org/10.3362/9781780445908.004

[25] Macmillan, H. (1931) Report of the Committee on Finance and Industry. CMD 3897, HMSO, London.

[26] Blanton, W.R. and Dorman, T.L. (1994) Small Business Spotlight SBA... Loans for Community Banks. Journal of Commercial Lending, 76, .

[27] Riding, A.L. and Short, D.M. (1987) Some Investor and Entrepreneur Perspectives on the Informal Market for Risk Capital. Journal of Small Business and Entrepreneurship, 4, 19-30. http://dx.doi.org/10.1080/08276331.1987.10600291

[28] Stiglitz, J. and Weiss, A. (1981) Credit Rationing in Markets with Imperfect Information. The American Economic Review, 71, 393-410.

[29] Kirzner, I. (1979) Perception, Opportunity, and Profit. University of Chicago Press, Chicago.

[30] Levin, R.C., Klevorick, A.K., Nelson, R.R. and Winter, S.G. (1987) Appropriating the Returns from Industrial Research and Development. Brookings Papers on Economic Activity, 1987, 783-831. http://dx.doi.org/10.2307/2534454

[31] Hall, G. (1996) Surviving and Prospering in the Small Firm Sector. Routledge, London.

[32] Deakins, D. and Philpott, T. (1993) Comparative European Practices in the Finance of Small Firms. UK, Germany and Holland. Discussion Paper. Polytechnic Business School, Birmingham. Demand for Finance of Small Scale Enterprises in Ghana. Discussion Paper, No. 251.

[33] Sharon, M. (2013) Bridging the Financing Gap in SMEs. http://www.scribd.com/doc/133559031/Bridging-the-Financing-Gap-in-Smes

[34] (2005) OECD The SME Financing Gap: Theory and Evidence. Vol. 1, 15.

[35] Haynes, G.W., Ou, C. and Berney, R. (1999) Small Business Borrowing from Large and Small Banks in Business Access to Capital and Credit. Federal Reserve System Research Conference, 8 March 1999, 287-327.

[36] Aktaş, C. (2010) The SMES in the Global World: Issues and Prospects. http://adfimi.org/dosyalar/seminerler/128/pdf/4.pdf

[37] Idowu, F.C. (2010) Impact of Microfinance on Small and Medium-Sized Enterprises in Nigeria.

[38] Akerlof, G.A. (1970) The Market for “Lemons”: Quality, Uncertainty, and the Market Mechanism. Quarterly Journal of Economics, 84, 488-500. http://dx.doi.org/10.2307/1879431

[39] World Bank World Development Report 2001. World Bank, Washington DC.

[40] Fafchamps, M. (1996) Risk Sharing and Quasi-Credit, and the Enforcement of Informal Risk Sharing Arrangement. Department of Economics, Stanford University, Stanford, (Mimeograph).

[41] Kon, Y. and Storey, D.J. (2003) A Theory of Discouraged Borrowers. Small Business Economics, 21, 37-49. http://dx.doi.org/10.1023/A:1024447603600 
[42] Fraser, S. (2005) Finance for Small and Medium-Sized Enterprises. Report on the 2004 UK Survey of SME Finance, Centre for Small and Medium-Sized Enterprises, Warwick Business School, University of Warwick, Coventry.

[43] Roper, S. and Scott, J. (2007) Gender Differences in Access to Start-Up Finance: An Econometric Analysis of GEM Data. 30th ISBE Conference, Glasgow, 7-9 November 2007.

[44] Stiglitz, J. and Weis, A. (1981) Credit Rationing in Markets with Imperfect Information. American Economic Review, 71, 393-410.

[45] Bester, H. (1987) The Role of Collateral in Credit Markets with Imperfect Information. European Economic Review, 31, 887-889. http://dx.doi.org/10.1016/0014-2921(87)90005-5

[46] Coleman, S. (2000) Access to Capital and Terms of Credit: A Comparison of Men and Women-Owned Small Businesses. Journal of Small Business Management, 38, 37-52.

[47] Hall, G., Hutchinson, P. and Michaelas, N. (2000) Industry Effects on the Determinants of Unquoted SMEs' Capital Structure. International Journal of the Economics of Business, 7, 297-312.

[48] Schmid, F. (2001) Equity Financing and the Entrepreneurial Firm. Federal Reserve Bank of St. Louis Review, 83, 1528.

[49] Hsu, D. (2004) What Do Entrepreneurs Pay for Venture Capital Affiliation? The Journal of Finance, 59, $1805-1844$. http://dx.doi.org/10.1111/j.1540-6261.2004.00680.x

[50] Shane, S. and Cable, D. (2002) Network Ties, Reputation, and the Financing of New Ventures. Management Science, 48, 364-382. http://dx.doi.org/10.1287/mnsc.48.3.364.7731

[51] OECD (2008) Rural Policy Reviews: Scotland UK-Assessment and Recommendations. OECD, Paris.

[52] Mensah, S. (2004) A Review of SME Financing Schemes in Ghana. UNIDO Regional Workshop of Financing SMEs, Accra, 15-16 March 2004.

[53] Alfred, S. and Xiao, W. (2013) Financing Family Business in Ghana, Challenges and the Way Forward. http://www.garph.co.uk/IJARMSS/Dec2013/14.pdf

[54] Kauffmann, C. (2005) Financing SMEs in Africa.

[55] Robinson, M. (1998) The Paradigm Shift From Credit Delivery to Sustainable Financial Intermediation. In: Kimenyi, M.S., Wieland, R.C. and Von Pischke, J.D., Eds., Strategic Issues in Microfinance, Ashgate Publishing, Aldershot.

[56] General Background on Global Microfinance Trends. http://www.mofep.gov.gh/sites/default/files/pages/microfinance_0.pdf

[57] Asiama, J. (2007) Microfinance in Ghana: An Overview. Department of Research, Bank of Ghana, 1-15.

[58] Kumasi Metropolitan Assembly about This Metropolis. http://www.kma.ghanadistricts.gov.gh/?arrow=atd\&_=6\&sa=5477

[59] Ghana Statistical Service (GSS) (2012) 2010 Population and Housing Census, Accra, Ghana: Ghana Statistical Service. http://www.statsghana.gov.gh/docfiles/2010phc/2010_POPULATION_AND_HOUSING_CENSUS_FINAL_RESUL TS.pdf

[60] Wolcott, H. (1990) Writing up Qualitative Research. Sage, Newbury Park.

[61] Yin, R.K. (1994) Case Study Research Design and Methods. 2nd Edition, Sage Publications, London.

[62] Solomon, K.F., William, A.A. and Abraham, O. (2012) The Effects of Cultural Values and Practices on the Development of Small and Medium Scale Enterprises in the Ashanti Region of Ghana. http://garph.co.uk/IJARMSS/Oct2012/1.pdf

[63] Rhyme, E. and Otero, M. (1992) Financial Services for Microenterprises Principles and Institutions. World Development, 20, 1561-1571. http://dx.doi.org/10.1016/0305-750X(92)90014-M 
Scientific Research Publishing (SCIRP) is one of the largest Open Access journal publishers. It is currently publishing more than 200 open access, online, peer-reviewed journals covering a wide range of academic disciplines. SCIRP serves the worldwide academic communities and contributes to the progress and application of science with its publication.

Other selected journals from SCIRP are listed as below. Submit your manuscript to us via either submit@scirp.org or Online Submission Portal.
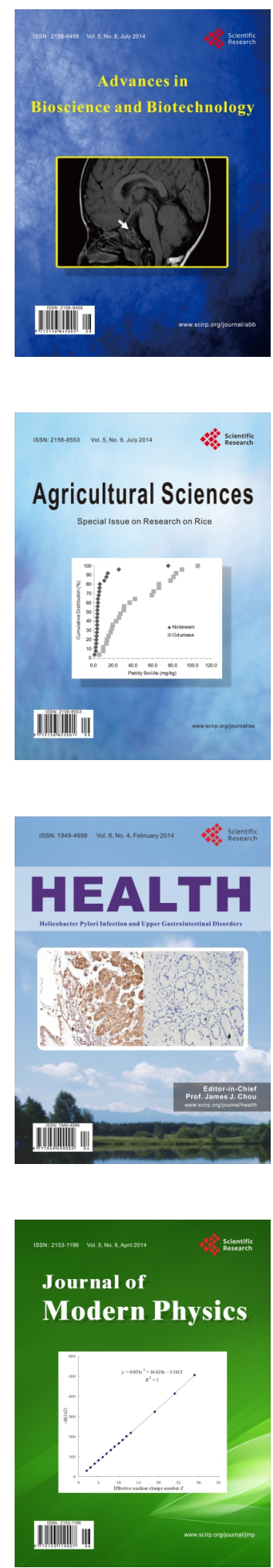
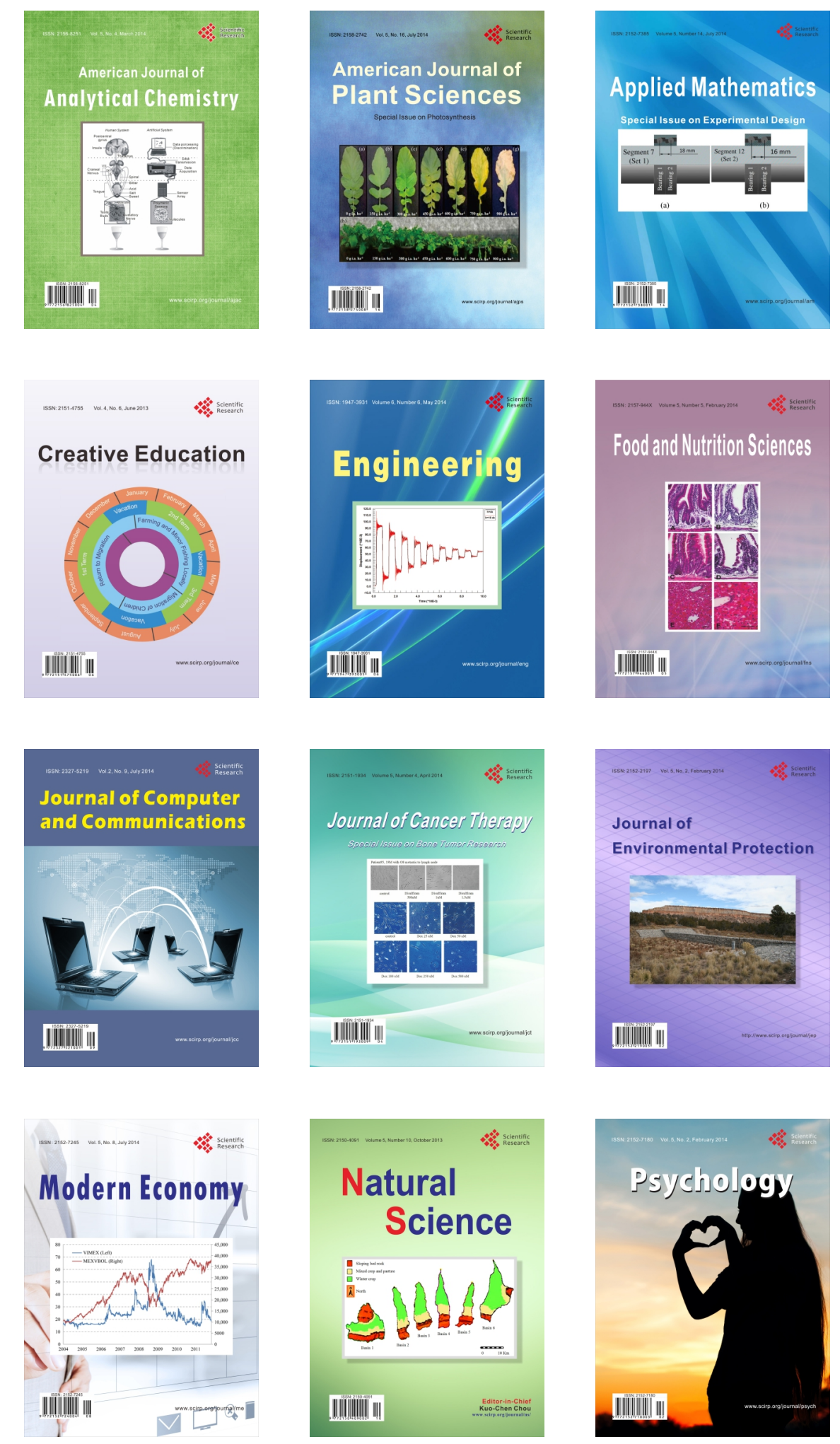